\title{
The Potential of Agro-homeopathy Applied to Medicinal Plants -A Review
}

\author{
M. M. A. Pereira ${ }^{1}$, A. D. Martins ${ }^{1}$, L. C. Morais ${ }^{1}$, J. Dória ${ }^{1}$, V. P. Cavalcanti ${ }^{1}$, F. A. Rodrigues ${ }^{1}$, \\ M. Pasqual ${ }^{1} \&$ J. M. Q. Luz $^{2}$ \\ ${ }^{1}$ Department of Agriculture, Federal University of Lavras, Brazil \\ ${ }^{2}$ Department of Agriculture, Federal University of Uberlância, Brazil \\ Correspondence: M. M. A. Pereira, Department of Agriculture, Federal University of Lavras, Brazil. Tel: \\ 55-991-004-598. E-mail: agro.maysa@gmail.com
}

Received: December 16, 2018

Accepted: January 18, 2019

Online Published: March 15, 2019

doi:10.5539/jas.v11n4p500

URL: https://doi.org/10.5539/jas.v11n4p500

\begin{abstract}
The homeopathic preparations can influence the growth, secondary metabolites production, essential oil yield and phytochemical profile when applied in the grown of medicinal plants. To compile this review articles from existing literature about basic research related to the use of homeopathic preparation on the cultivation of medicinal plants and its influence on the phytochemical profile, growth, yield and composition of essential oil were collected. The bibliographic research was carried out in scientific databases sites-Scopus, Web of Science and PubMed. Seventeen publications were found in which homeopathy was applied in the cultivation of medicinal plants. Its use changed the phytochemical profile, increased the essential oil yield, the production of secondary metabolites (coumarins, alkaloids, phenylpropanoids), the the nutrients absorption and the growth of the medicinal plant species were studied. This review shows that the application of homeopathic preparations in the cultivation of medicinal plants increases the production of secondary metabolites and essential oils that are important for human and animal health therapeutic treatments. The homeopathic preparation application is an alternative for the growth of medicinal plants with ecological balance, and without soil and water contamination. It is also affordable to farmers and researchers. However, further studies are required on its influence on the phytochemical profile of the cultivated medicinal species.
\end{abstract}

Keywords: agroecology, homeopathy, in vivo, secondary metabolites

\section{Introduction}

Medicinal plants are important for health maintenance; it is considered the most affordable therapeutic treatment used by $80 \%$ of the population (Moreira, 2010). The cultivation of medicinal plants need to be based on agroecological agriculture, without the use of synthetic chemical products that contaminate soil, environment and the plants with therapeutic purposes (Willer et al., 2010; Santos et al., 2014).

Therefore, there is an increase in the number of farmers and researchers seeking for natural and ecological alternatives aiming to obtain medicinal plants free of chemical residues (Brasil, 2011; Moreno, 2017). Besides improvement in growth, there is also increase of secondary metabolites production, essential oil and phytochemicals with pharmacological and biological interest (Moura et al., 2017; Nunes et al., 2018).

The use of homeopathy in agriculture has been changing conventional agriculture to agroecological (Andrade et al., 2011), through the application of homeopathic preparations in different dynamization, following the Homeopathic Pharmacopoeia guidelines proposed by Hahnemann in 1810 (Hahnemann, 2013). The homeopathic dynamizations follow the principles of disintegration of matter and radiation without nuclear rupture, through the mechanical action on the smaller particles and addition of inert substances with dynamic activity, following the laws of electromagnetic waves: frequency, length and amplitude (Bonato, 2008).

Homeopathic preparations can be applied on the soil and/or on the leaves (Santos et al., 2011; Andrade et al., 2012). These preparations can increase or decrease the production of bioactive substances due to its influence on the primary and secondary metabolism of medicinal plants modifying its phytochemical profile (Capra et al., 2014; Verdi et al., 2016). The application of nosodes and biotherapeutics are the most applied techniques in agro-homeopathy (Jãger et al., 2010; Moreno et al., 2018). 
The present review aims to compile the basic homeopathy research existing in the literature applied to the cultivation of medicinal plants and to verify its influence on the plant growth, phytochemical profile, yield and composition of the essential oils.

\section{Methods}

The bibliographical research was accomplished by compiling the publications from the databases Scopus, Web of Science and PubMed that evaluated the application of the homeopathic preparations in the growth of medicinal plants. To carry out this research, different key words related to this subject were used, such as medicinal plants + homeopathy + cultivation + secondary metabolism, soil, essential oil. All the objectives, results and conclusions sections of the papers found were analysed for the writing of this review.

Scientific articles, term paper, master's degree dissertation and doctoral thesis that researched the application of homeopathic preparation in the soil, leaves pulverization and evaluated its influence on the growth, essential oil yield and phytochemical profile were included in this review.

\section{Results}

Seventeen studies carried out between 2002 and 2016 were found in the search. They evaluated the influence of homeopathic preparation in the cultivation, essential oil yield and phytochemical profile of 11 medicinal species (Table 1). They analysed nineteen homeopathic preparations in different dynamizations, being Phosphorus, Sulfur and Silicea the most studied ones (Almeida, 2002; Castro, 2002a, 2002b, 2003; Duarte, 2007; Bonato et al., 2009; Gonçalvez, 2010; Santos et al., 2011; Capra et al., 2014; Verdi et al., 2016).

Table 1. Abstract of medicinal plants species elicited by boosted homeopathics

\begin{tabular}{|c|c|c|c|c|c|c|c|}
\hline $\begin{array}{l}\text { Scientific } \\
\text { Name }\end{array}$ & $\begin{array}{l}\text { Application } \\
\text { via }\end{array}$ & Source/Treatment & Evaluation & $\begin{array}{l}\text { Pharma- } \\
\text { cogenetic }\end{array}$ & $\begin{array}{l}\text { Efficient } \\
\text { treatment }\end{array}$ & Results & Authors \\
\hline $\begin{array}{l}\text { Ocimum } \\
\text { basilicum L. }\end{array}$ & Soil & $\begin{array}{l}\text { Arsenicum album, Carbo } \\
\text { vegetabilis, Calcarea } \\
\text { carbonica, Phosphorus, } \\
\text { Sulphur, Silicea and Cuprum } \\
\text { (30ch) }\end{array}$ & Essential oil & Leaf & $\begin{array}{l}\text { Phosphorus } \\
30 \mathrm{cH}\end{array}$ & $\begin{array}{l}\text { Sulphur } 30 \mathrm{cH}(52.73 \%), \\
\text { Calcarea carbonica } 30 \mathrm{cH} \\
(47.37 \%) \text { and Carbo } \\
\text { vegetabilis } 30 \mathrm{cH}(27.27 \%):< \\
\text { Essential oil; } \\
\text { Phosphorus } 30 \mathrm{cH}:>\text { Essential } \\
\text { oil }(130 \%)\end{array}$ & $\begin{array}{l}\text { Almeida } \\
(2002)\end{array}$ \\
\hline $\begin{array}{l}\text { Cymbopogon } \\
\text { citratus } \mathrm{L} .\end{array}$ & Soil and leaf & $\begin{array}{l}\text { Humic acid, isoterapic and } \\
\text { Sulphur (3c, 12c, 30c, 200c, } \\
1000 \mathrm{c}) \text {, control }\end{array}$ & $\begin{array}{l}\text { Essential oil, } \\
\text { concentrations of } \\
\text { neral, geranial and } \\
\text { citral }\end{array}$ & Leaf & $\begin{array}{l}\text { Sulphur and } \\
\text { Isoterápico } \\
12 \mathrm{c}\end{array}$ & $\begin{array}{l}\text { Humic acid } 12 c \text { and Sulphur } \\
12 c:>\text { Rates of the neral and } \\
\text { geraniol; } \\
\text { Sulphur } 30 c:>\text { Rates of the } \\
\text { neral; } \\
\text { Isoterapic } 12 c:>\text { Bioomass } \\
\text { and essential oil }\end{array}$ & $\begin{array}{l}\text { Castro } \\
(2002)\end{array}$ \\
\hline $\begin{array}{l}\text { Justicia } \\
\text { pectoralis } \\
\text { Jacq. }\end{array}$ & Soil and leaf & $\begin{array}{l}\text { Humic acid, isoterapic and } \\
\text { Sulphur (3c, 12c, 30c, 200c, } \\
1000 \mathrm{c}) \text {, control }\end{array}$ & $\begin{array}{l}\text { Methanolic extract } \\
\text { and coumarin content }\end{array}$ & Leaf & $\begin{array}{l}\text { Sulphur and } \\
\text { Isoterápico } \\
200 \mathrm{c}\end{array}$ & $\begin{array}{l}\text { Sulphur } 30 c \text { : }>\text { rates of the } \\
\text { methanolic extract; } \\
\text { Humic acid } 12 c, 30 c \text { and } \\
200 c \text { : }>\text { Coumarin content; } \\
\text { Humic acid } 200 c \text { : }>\text { Coumarin } \\
\text { in }(353 \%)\end{array}$ & $\begin{array}{l}\text { Castro } \\
(2002)\end{array}$ \\
\hline $\begin{array}{l}\text { Ageratum } \\
\text { conyzoides } \mathrm{L} \text {. }\end{array}$ & Soil & $\begin{array}{l}\text { Ageratum conyzoides L. (2c, } \\
4 \mathrm{c}, 6 \mathrm{c}, 30 \mathrm{c}, 60 \mathrm{c}, 200 \mathrm{c}) \text { and } \\
\text { control (root, shoot and } \\
\text { whole plant) }\end{array}$ & $\begin{array}{l}\text { Growth, essential oil } \\
\text { and coumarin content }\end{array}$ & Leaf & $\begin{array}{l}\text { Ageratum } \\
\text { conyzoides } \mathrm{L} . \\
2 \mathrm{c}, 6 \mathrm{c}, 30 \mathrm{c}\end{array}$ & $\begin{array}{l}\text { Ageratum conyzoides } L .30 c \\
\text { and } 4 c \text { whole plant: }< \\
\text { Essential oil; } \\
\text { Ageratum conyzoides } L .2 c \\
\text { whole plant: }>\text { Essential oil } \\
(62 \%) ; \\
\text { Ageratum conyzoides } L .6 c \\
\text { and } 30 \text { c root: }>\text { Coumarin } \\
\text { contente }\end{array}$ & (2003) \\
\hline $\begin{array}{l}\text { Cymbopogon } \\
\text { citratus } \mathrm{L} .\end{array}$ & Soil & $\begin{array}{l}\text { Humic acid (AH), isoterapic } \\
\text { Cymbopogon citratus } \mathrm{L} \text {. } \\
(\mathrm{ISO}) \text { and Sulphur }(\mathrm{S})(3 \mathrm{c} \text {, } \\
12 \mathrm{c}, 30 \mathrm{c}, 200 \mathrm{c}, 1000 \mathrm{c})\end{array}$ & Essential oil & Leaf & $\begin{array}{l}\text { Cymbopogon } \\
\text { citratus } \mathrm{L} .6 \mathrm{c} \\
\text { and } 12 \mathrm{c}\end{array}$ & $\begin{array}{l}\text { Cymbopogon citratus L. } 6 c \\
\text { and } 12 c \text { : positive effect; } \\
\text { Cymbopogon citratus } L .200 c \text { : } \\
\text { negative effect }\end{array}$ & $\begin{array}{l}\text { Castro et } \\
\text { al. }(2003)\end{array}$ \\
\hline $\begin{array}{l}\text { Tanacetum } \\
\text { parthenium } \mathrm{L} \text {. }\end{array}$ & Soil & $\begin{array}{l}\text { Arnica montana }(1 \mathrm{dH}, 2 \mathrm{dH}, \\
\mathrm{dH} 3,4 \mathrm{dH} \text { and } 5 \mathrm{dH})\end{array}$ & $\begin{array}{l}\text { Fresh biomass and } \\
\text { parthenolide content }\end{array}$ & Leaf & $\begin{array}{l}\text { Arnica } \\
\text { montana } \\
(1 \mathrm{dH}, 2 \mathrm{dH}, \\
4 \mathrm{dH} \text { and } 5 \mathrm{dH})\end{array}$ & $\begin{array}{l}>\text { Plant height } \\
<\text { Parthenolide content }\end{array}$ & $\begin{array}{l}\text { Carvalho } \\
\text { et al. } \\
(2003)\end{array}$ \\
\hline
\end{tabular}




\begin{tabular}{|c|c|c|c|c|c|c|c|}
\hline $\begin{array}{l}\text { Bidens pilosa } \\
\text { L. }\end{array}$ & Soil & $\begin{array}{l}\text { Alumina } 3 \mathrm{cH} \text {, Nitricum } \\
\text { acidum, Natrum muriaticum, } \\
\text { Calcarea carbonica, Calcarea } \\
\text { phosphorica, Sulphur, China, } \\
\text { Magnesia carbonica and } \\
\text { controls } 70 \% \text { ethanol and } \\
\text { distilled water and China } \\
(2 \mathrm{c}, 4 \mathrm{c}, 8 \mathrm{c}, 10 \mathrm{c}, 12 \mathrm{c}, 14 \mathrm{c}, \\
16 \mathrm{c}, 18 \mathrm{c}, 20 \mathrm{c}, 22 \mathrm{c} \text {, and } 24 \mathrm{c})\end{array}$ & $\begin{array}{l}\text { Morphological } \\
\text { response, essential oil } \\
\text { content, catalase and } \\
\text { peroxidase enzymatic } \\
\text { activity, production } \\
\text { of antimalarial } \\
\text { compounds }\end{array}$ & Leaf & China $3 \mathrm{cH}$ & $\begin{array}{l}\text { China } 3 \mathrm{cH} \text { : > Fresh biomass } \\
\text { Enzymatic activity of } \\
\text { peroxidase and catalase was } \\
\text { not influenced by } \\
\text { homeopathic preparations }\end{array}$ & $\begin{array}{l}\text { Armond } \\
\text { et al. } \\
(2003)\end{array}$ \\
\hline $\begin{array}{l}\text { Tanacetum } \\
\text { parthenium } \\
\text { (L.) } \\
\text { Schultz-Bip }\end{array}$ & Soil & Natrum muriaticum $(2 \mathrm{cH})$ & Proline & Leaf & $\begin{array}{l}\text { Natrum } \\
\text { muriaticum } \\
2 \mathrm{cH}\end{array}$ & $\begin{array}{l}>\text { Chlorophyll and proline } \\
\text { levels }\end{array}$ & $\begin{array}{l}\text { Carvalho } \\
\text { et al. } \\
(2004)\end{array}$ \\
\hline $\begin{array}{l}\text { Bidens pilosa } \\
\text { L. }\end{array}$ & Soil & Solutions from China & $\begin{array}{l}\text { Growth, flavanoid } \\
\text { levels, acetylene and } \\
\text { essential oils }\end{array}$ & - & $\begin{array}{l}\text { Solutions } \\
\text { from China }\end{array}$ & $\begin{array}{l}\text { Changes on the phitochemical } \\
\text { spectrum }\end{array}$ & $\begin{array}{l}\text { Armond } \\
\text { et al. } \\
(2005)\end{array}$ \\
\hline $\begin{array}{l}\text { Tanacetum } \\
\text { parthenium } \\
\text { (L.) } \\
\text { Schultz-Bip }\end{array}$ & Soil & Arnica montana & Partenolides & $\begin{array}{l}\text { Dry } \\
\text { aerial } \\
\text { part }\end{array}$ & $\begin{array}{l}\text { Arnica } \\
\text { montana }\end{array}$ & $\begin{array}{l}\text { Height and fresh mass haven't } \\
\text { been modified cause of the } \\
\text { solutions }<\text { Partenolide levels } \\
3 \mathrm{cH} \text { and } 5 \mathrm{cH}\end{array}$ & $\begin{array}{l}\text { Carvalho } \\
\text { et al. } \\
(2005) \text {. }\end{array}$ \\
\hline $\begin{array}{l}\text { Eucalyptus } \\
\text { citriodora \& } \\
\text { Eucalyptus } \\
\text { globulus }\end{array}$ & Soil & $\begin{array}{l}\text { Phosphorus }(3 \mathrm{cH}, 6 \mathrm{cH} \text {, } \\
12 \mathrm{cH}, 30 \mathrm{cH}, 100 \mathrm{cH}, 200 \mathrm{cH} \text {, } \\
1000 \mathrm{cH} \text { and } 5000 \mathrm{cH})\end{array}$ & $\begin{array}{l}\text { Growth and essential } \\
\text { oil }\end{array}$ & Leaf & $\begin{array}{l}\text { Phosphorus } \\
12 \mathrm{cH}\end{array}$ & $>$ Essential oil & $\begin{array}{l}\text { Duarte } \\
(2007)\end{array}$ \\
\hline $\begin{array}{l}\text { Mentha } \\
\text { arvensis L. }\end{array}$ & Soil & $\begin{array}{l}\text { Sulphur }(3 \mathrm{cH}, 5 \mathrm{cH}) \text { and } \\
\text { Arsenicum }(3 \mathrm{cH})\end{array}$ & Essential oil & $\begin{array}{l}\text { Dry } \\
\text { leaves }\end{array}$ & $\begin{array}{l}\text { Arsenicum } \\
3 \mathrm{cH}\end{array}$ & $\begin{array}{l}\text { Sulfur Boosted > Essential oil } \\
\text { levels } 34 \% \text { and } 21 \% \\
\text { Arsenium }>\text { Oil rates in } 45 \\
\text { and } 21 \% \text {, for } 24 \text { and } 30 \mathrm{cH} \\
>\text { Photosynthetic rates }\end{array}$ & $\begin{array}{l}\text { Bonato et } \\
\text { al. }(2009)\end{array}$ \\
\hline $\begin{array}{l}\text { Talinum } \\
\text { triangulare } \\
\text { (Jacq.) Willd } \\
\text { (Portulacaceae) }\end{array}$ & Soil & $\begin{array}{l}\text { Phosphorus }(3 \mathrm{cH}, 6 \mathrm{cH} \text {, } \\
12 \mathrm{cH}, 30 \mathrm{cH}, 100 \mathrm{cH}) \text { and } \\
\text { control (energized water) }\end{array}$ & $\begin{array}{l}\text { Production of } \\
\text { flavanoids and } \\
\text { antioxidant capacity } \\
\text { of the plant extract }\end{array}$ & Leaf & $\begin{array}{l}\text { Phosphorus } \\
3 \mathrm{cH}, 12 \mathrm{cH} \\
\text { and } 30 \mathrm{cH}\end{array}$ & $\begin{array}{l}>\text { Content of flavonoids } \\
>\text { Antioxidant activity }\end{array}$ & $\begin{array}{l}\text { Gonçalvez } \\
\text { (2010) }\end{array}$ \\
\hline $\begin{array}{l}\text { Verbena } \\
\text { gratissima }\end{array}$ & Soil & Phosphorus $(9 \mathrm{cH})$ & $\begin{array}{l}\text { Growth and essential } \\
\text { oil }\end{array}$ & Leaf & $\begin{array}{l}\text { Phosphorus } \\
9 \mathrm{cH}\end{array}$ & $\begin{array}{l}>\text { Growth, fresh biomass. } \\
\text { influenced the composition of } \\
\text { the essential oil with increase } \\
\text { of beta-pinene acetate, } \\
\text { trans-pinocarveol, } \\
\text { trans-pinocamphone and } \\
\text { trans-pinocarvyl acetate }\end{array}$ & $\begin{array}{l}\text { Santos et } \\
\text { al. (2011) }\end{array}$ \\
\hline $\begin{array}{l}\text { Justicia } \\
\text { pectoralis } \\
\text { Jacq. }\end{array}$ & Pulverization & Justicia & $\begin{array}{l}\text { Morphologic } \\
\text { features, coumarin } \\
\text { levels, } \\
\text { eletromagnetic field }\end{array}$ & Leaf & Justicia & $\begin{array}{l}\text { Justicia, Arnica montana, } \\
\text { Phosphorus }>\text { Coumarin } \\
\text { levels } 54.35 \% \text {; } \\
\text { Humic Acid }>55.10 \% \text { Justicia }\end{array}$ & $\begin{array}{l}\text { Andrade } \\
\text { et al. } \\
(2012)\end{array}$ \\
\hline $\begin{array}{l}\text { Baccharis } \\
\text { trimera (Less.) } \\
\text { DC. }\end{array}$ & $\begin{array}{l}\text { Pulverization } \\
\text { Leaf }\end{array}$ & $\begin{array}{l}\text { Silicea (cH6, cH12, cH30, } \\
7 \mathrm{dH}), \text { Equisetum }(7 \mathrm{dH}) \text { and } \\
\text { control }\end{array}$ & $\begin{array}{l}\text { Fresh and dry } \\
\text { biomass, quercetin } \\
\text { content }\end{array}$ & Leaf & $\begin{array}{l}\text { Silicea cH6, } \\
7 \mathrm{dH} \text { and } \\
\text { Equisetum } \\
7 \mathrm{dH}\end{array}$ & $\begin{array}{l}\text { Silicea cH6 and } 7 d H:> \\
\text { Quercetina contente } 30 \% \text { and } \\
47 \% \text {, respectively; } \\
\text { Equisetum } 7 d H:>\text { Quercetina } \\
\text { content }(45 \%)\end{array}$ & $\begin{array}{l}\text { Capra et } \\
\text { al. }(2014)\end{array}$ \\
\hline $\begin{array}{l}\text { Ocimum } \\
\text { basilicum } \mathrm{L} .\end{array}$ & $\begin{array}{l}\text { Pulverization } \\
\text { Leaf }\end{array}$ & $\begin{array}{l}\text { Silicea }(7 \mathrm{cH}, 12 \mathrm{cH}, 30 \mathrm{cH}) \\
\text { and Equisetum }(12 \mathrm{cH}, 14 \mathrm{cH} \text {, } \\
16 \mathrm{cH}) \text { and distilled water }\end{array}$ & Essential oil & Leaf & Silicea $30 \mathrm{cH}$ & $>$ Essential oil yield $141 \%$ & $\begin{array}{l}\text { Verdi et } \\
\text { al. (2016) }\end{array}$ \\
\hline
\end{tabular}

The researchers observed that homeopathic preparations can improve the photosynthetic rates through changes in the physiological mechanisms, as the allocation of greater levels of photo-assimilated compounds in the leaves boosted growth (Bonato et al., 2009; Andrade, 2012).

The homeopathic application of Natrum muriaticum $2 \mathrm{cH}$ via soil increased the content of chlorophyll in the leaves of Tanacetum parthenium; it also increased the photosynthetic rates and the biomass production (Carvalho, 2004). The same homeopathic preparation applied during the cultivation of Mentha arvensis (Carvalho, 2004) changed the photosynthetic rates of this species. These results can be related to the higher number of chlorophyll molecules that increases the capacity of light absorption and induces rubisco activity, leading to higher carbon absorption. This increases the synthesis of fundamental compounds for the secondary metabolism, which are responsible for the production of bioactive molecules with therapeutic properties. 
According to Ramzam (2015) the synthesis of glucose molecule through physiological processes (photosynthesis and respiration) produces organic compounds (sucrose). In addition to providing energy for plant growth and development they also act on the precursors of shikimic acid and acetate. These precursors form the mevalonate (MEV) and 1-Deoxy-D-xylulose 5-phosphate (DXP) pathways. These pathways are the origin of some secondary metabolism categories such as flavonoids, tannins, alkaloids, phenolic compounds, terpenoids and others.

Biotic and abiotic factors are related to plant growth, the physiology and biochemical plants response (Capra, 2014). Changes in the environmental conditions in response to the application of homeopathic preparations can redirect metabolic pathways with influence on the production of secondary metabolites, fresh and dry biomass production, yield and chemical composition of the essential oils in medicinal plants (Carvaho, 2004; Bonato, 2009; Andrade, 2012; Capra, 2014; Verdi, 2016).

Application of Justicia Isotherapic increased coumarin content on the leaves and stem of Justicia pectoralis Jacq. This result reaffirms that at the principle of similitude there is a response from the plants vital energy that canalize its energy for the production of secondary metabolites with pharmacologic activity (Andrade, 2012) such as antioxidant, antiasthmatic, (Cameron et al., 2015; Moura et al., 2017), anti-inflammatory (Nunes et al., 2018).

The application of homeopathic preparations on the soil and/or on the leaves can change the phytochemical profile of medicinal species (Castro, 2002b; Duarte, 2003; Armond et al., 2005; Gonçalvez, 2010; Santos et al., 2011; Andrade et al., 2012; Capra et al., 2014) and it can increase the essential oil yield (Almeida, 2002; Castro, 2002a; Duarte, 2003; Duarte, 2007; Bonato et al., 2009; Verdi, 2016). On the other hand, Carvalho et al. (2003) and Armond et al. (2003) observed a reduction in the production of secondary metabolites and no influence in the peroxidase and catalase enzymatic production when homeopathic preparation was applied on the species Tanacetum parthenium L. and Bidens pilosa L, respectively.

Homeopathic preparation affected the chromatographic profile of the essential oil of Bidens pilosa L. (Armond, 2005) showing distinctive peaks of organic acids like chlorogenic acid, acetylenes, flavonoids, which are bioactive molecules with antimalarial function. Therefore, the efficiency of the homeopathy to change the phytochemical spectrum, and to increase the yield of essential oils in plants used as medicine for humans health is of great social and economic importance.

Ten out of seventeen studies on this work showed changes in the phytochemical profile of the medicinal plants as a function of homeopathic preparations. Castro (2002a) in applying Sulphur and isotherapeutic 12c observed an alteration in the phytochemical profile of Cymbopogon citratus L. with an increase of neral and geraniol content. These compounds are used in the traditional medicine due to its antispasmodic and analgesics activity (Sadraei et al., 2015).

According to Castro (2002b) and Duarte (2003) the application of homeopathic preparations-Sulphur, Humic Acid 200c and Ageratum conyzoides L. 2c, 6c, 30c-in different dynamizations during the grown of Justicia pectoralis Jacq. and Ageratum conyzoides L. increased over 353\% the coumarin content when compared to the control treatment. Evidences have shown that coumarin presents anti-inflammatory, antinociceptive, antispasmodics, muscle relaxant and anxiolytic properties, with great potential on the development of phytoterapics (Leal et al., 2017).

The application of Phosphorus via soil in dynamizations $(3 \mathrm{cH}, 12 \mathrm{cH}$ and $30 \mathrm{cH})$ increased the levels of flavonoids responsible for antioxidant activity of the plants Talinum triangulare (Jacq.) Willd (Portulacaceae) (Gonçalvez, 2010; Liao et al., 2015). Phosphorus in the dynamization $9 \mathrm{cG}$ enhanced the production of beta-pineno acetatus, trans-pinocarveol, trans-pinocamphone and trans-pinocarvyl molecules in plants of Verbena gratissima therapeutically used due to its antimicrobial property (Santos et al., 2011). Capra et al. (2014) verified an increase of $30 \%$ and $47 \%$ in the content of quercetin in response to the application of Silicea $6 \mathrm{cH}, 7 \mathrm{dH}$ and Equisetum $7 \mathrm{dH}$, respectively, in the Baccharis trimera cultivation. This compound is widely employed in the treatment of liver diseases, diabetes and digestive disorders (Pádua et al., 2010).

However, negative effects were also found by the researches Carvalho et al. (2003) and Carvalho et al. (2005). The use of Arnica montana in 5 dynamizations and and Natrum muriaticum $2 \mathrm{cH}$ in the cultivation of Tanacetum parthenium (L.) Schultz-Bip decreased the partenolidium content, an active principle that acts in carcinogenic cells. 


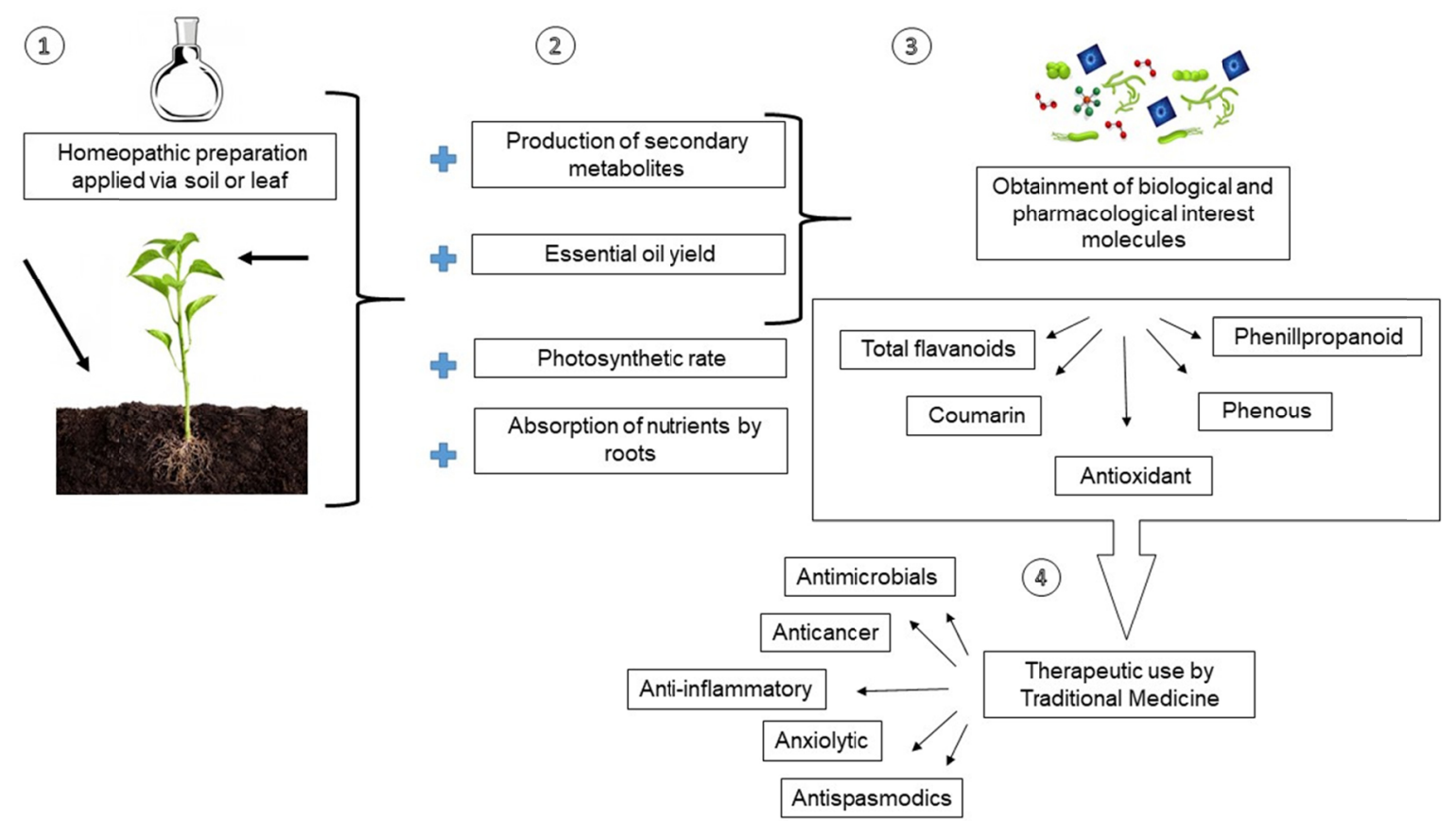

Figure 1. Benefits of the application of homeopathic preparations in the cultivation of medicinal plants

\section{Final Considerations}

The homeopathic preparations applied on the soil or on the leaf during the cultivation of medicinal plants changed the phytochemical spectrum, increased the essential oil production and yield, photosynthesis rates and the potential for the production of active principles with pharmacological and biological properties. Those compounds have therapeutic use such as antioxidants, anticancer, antispasmodics, and antimicrobials among others properties. Research approaching the use of homeopathy in the cultivation of medicinal plants is highly relevant for being a lifelong practice that aims at not only the optimization of production but also the quality of chemical constituents. Besides being an accessible practice to farmers, it contributes to the strengthening of agroecology and the expansion of the productivity chain of medicinal plants. However, further studies are needed to understand the influence of the application of homeopathic preparation in the cultivation of medicinal plants and how it affects the production of secondary metabolites and essential oil.

\section{References}

Almeida, M. A. Z. (2002). Basil (Ocimum basilicum L.) response to homeopathic treatments ( $\mathrm{PhD}$ Thesis, Federal University of Viçosa, Viçosa).

Andrade, F. M. C., Casali, V. W. D., \& Cecon, P. R. C. (2012). Growth and production of coumarin in the plants of chambá (Justicia pectoralis Jacq.) treated with isoterapic. Revista Brasileira de Plantas Medicinais, 14, 154-158. https://doi.org/10.1590/S1516-05722012000500005

Andrade, F. M. C., Casali, V. W. D., \& Cecon, P. R. C. (2012). Growth and production of coumarin in the plants of chambá (Justicia pectoralis Jacq.) treated with isoterapic. Revista Brasileira de Plantas Medicinais, 14, 154-158. https://doi.org/10.1590/S1516-05722012000500005

Andrade, F. M. C., Casali, V. W. D., \& Cupertino, M. do C. (2011). Homeopatia, Agroecologia e Sustentabilidade. Revista Brasileira de Agroecologia, 6(1), 49-56

Andrade, F. M. C., Casali, V. W. D., DeVita, B., Cecon, P. R., \& Barbosa, L. C. A. (2001). Effect of homeopathy on growth and yield of coumarin in "chambá" (Justicia pectoralis Jacq.) Revista Brasileira de Plantas Medicinais, 4(1), 19-28. https://doi.org/10.1590/S1516-05722012000500005

Andrade, F. M. C., Casali, V. W. D., DeVita, B., Cecon, P. R., \& Barbosa, L. C. A. (2001). Effect of homeopathy on growth and yield of coumarin in "chambá" (Justicia pectoralis Jacq.) Revista Brasileira de Plantas Medicinais, 4(1), 19-28. https://doi.org/10.1590/S1516-05722012000500005

Armond, C. (2003). Growth and chemical markers in plants of Bidens pilosa L. (Asteraceae) treated with homeopathy (PhD Thesis, Federal University of Viçosa, Viçosa). 
Armond, C., Casali, V. W. D., Cecon, P. R., Reis, E. L., Filho, L. N. C., ... Brandão, M. G. L. (2005). Essential oil and antimalarial compounds in plants of Bidens pilosa L. treated with the China homeopathy. Revista Brasileira de Plantas Medicinais, 7(3), 18-24.

Bonato, C. M., de Proença, G. T., \& Reis, B. (2009). Homeopathic drugs Arsenicum album and Sulphur affect the growth and essential oil content in mint (Mentha arvensis L.). Acta Scientiarum-Agronomy, 31(1), 101-105. https://doi.org/10.4025/actasciagron.v31i1.6642

Brasil. (2011). Farmacopeia homeopática brasileira (3rd ed.). Anvisa, Brazil.

Capra, R. S., Gratão, A. S., Freitas, G. B., \& Leite, M. N. (2014). Homeopathic preparations and crop environments through production and yield of quercetin on carqueja plants [Baccharis trimera (Less) DC.]. Revista Brasileira de Plantas Medicinais, 16(3), 566-573. https://doi.org/10.1590/1983-084X/13_043

Carvalho, L. M., Casali, V. W. D., Cecon, P. R., Lisboa, S. P., \& Souza, M. A. (2004). Effect of homeopathy on recovery of feverfew plants, Tanacetum parthenium (L.) Schultz Bip, under water stress. Revista Brasileira de Plantas Medicinais, 6(2), 20-27.

Carvalho, L. M., Casali, V. W. D., Cecon, P. R., Souza, M. A., \& Lisboa, S. P. (2003). Effect of decimal potencies of homeopathy Arnica montana on plantas of feverfew. Revista Brasileira de Plantas Medicinais, 6(1), 46-50.

Carvalho, L. M., Casali, V. W. D., Cecon, P. R., Souza, M. A., \& Lisboa, S. P. (2003). Effect of decimal potencies of homeopathy Arnica montana on plants of feverfew. Revista Brasileira de Plantas Medicinais, 6(1), 46-50.

Carvalho, L. M., Casali, V. W. D., Lisboa, S. P., Souza, M. A., \& Cecon, P. R. (2005). Effect of homeopathy Arnica montana, centesimal potencies, on plants of artemísia. Revista Brasileira de Plantas Medicinais, 7(3), 33-36.

Cassali, V. B., Azevedo, L. F. De, Ferreira, R. P., Silva, D. G. Da, \& Simão, R. S. (2014). Agrotóxicos: Uma Revisão De Suas Consequências Para a Saúde Pública. Revista Eletrônica Em Gestão, Educação e Tecnologia Ambiental, 18(1), 437-445. https://doi.org/10.5902/2236117012498

Castro, D. M. (2002). Homeopathic preparations in carrot, sugar-beet, lemongrass and chamba plants $(\mathrm{PhD}$ Thesis, Federal University of Viçosa, Viçosa).

Castro, D. M., Casali, V. W. D., Duarte, E. S. M., Armond, C., Arruda, V. M., Almeida, A. A., ... Cecon, P. R. (2003). Conteúdo relativo de óleo essencial na matéria seca de plantas de capim-limão submetidas à soluções homeopáticas. Horticultura Brasileira: Sociedade Brasileira de Olericultura, 21, 410.

Cristiane, B. De O., Lucimara, N. C., Adroaldo, L., Robson, H. A., Melissa, G. S. P., Gabriela, L. D. S., ... Grace, G. (2012). Phenolic Enriched Extract of Baccharis trimera Presents Anti-inflammatory and Antioxidant Activities. Molecules, 17, 1113-1123. https://doi.org/10.3390/molecules17011113

Duarte, E. S. M. (2003). Soluções homeopáticas, crescimento e produção de compostos bioativos em Ageratum conyzoides L. (ASTERACEAE) (Dissertation, Federal University of Viçosa, Viçosa).

Duarte, E. S. M. (2007). Crescimento e teor de óleo essencial em plantas de Eucalyptus citriodora e Eucalyptus globulus tratadas com homeopatia (PhD Thesis, Federal University of Viçosa, Viçosa).

Dung, Y. L., Yu, C. C., Sue, H. W., Chih, W. C., \& Ming, S. (2015). Antioxidant activities and contents of flavonoids and phenolic acids of Talinum triangulare extracts and their immunomodulatory effects. Journal of Food and Drug Analysis, 23(2), 294-302. https://doi.org/10.1016/j.jfda.2014.07.010

Hahnemann, S. (2013). Exposição da doutrina homeopática, ou, Organon da Arte de Curar. São Paulo: GEHSP "Benoit Mure".

Mallick, I., Bhattacharyyaa, C., Mukherjia, S., Deya, D., Sarkarb, S. C., Mukhopadhyayb, U. K., \& Ghosh, A. (2018). Effective rhizoinoculation and bio fi $\mathrm{lm}$ formation by arsenic immobilizing halophilic plant growth promoting bacteria (PGPB) isolated from mangrove rhizosphere: A step towards arsenic rhizoremediation. Science of the Total Environment, 611(610), 1239-1250. https://doi.org/10.1016/j.scitotenv.2017.07.234

Moreira, L. K. A., Silva, L. A. H., \& Viana, G. S. de B. (2017). Justicia pectoralis a coumarin medicinal plant have potential for the development of antiasthmatic drugs? Revista Brasileira de Farmacognosia, 6(27), 794-802.

Moreno, N. M. (2017). Agrohomeopatía como alternativa a los agroquímicos. Revista Médica de Homeopatía, 
10(1), 9-13. https://doi.org/10.1016/j.homeo.2017.04.004

Moura, C. T. M., Lima, F. J. B., Brito, T. S., Silva, A. A. V., Ferreira, L. C., Roque, C. R., ...Magalhães, P. J. C. (2017). Inhibitory effects of a standardized extract of Justicia pectoralis in an experimental rat model of airway hyper- responsiveness. Pharmacy and Pharmacology, 1-11. https://doi.org/10.1111/jphp.12689

Nunes, T. R. de S., Cordeiro, M. F., Beserra, F. G., Souza, M. L. de, da Silva, W. A. V., Magda, R. A. F., ... Moacyr, J. B. de M. R. (2018). Organic Extract of Justicia pectoralis Jacq. Leaf Inhibits Interferon? Secretion and Has Bacteriostatic Activity against Acinetobacter baumannii and Klebsiella pneumoniae. Evidence-Based Complementary and Alternative Medicine, 10. https://doi.org/10.1155/2018/5762368

Santos, F. M., Monfort, L. E., Castro, D. M., Pinto, J. E., Leonardi, M., \& Pistelli, L. (2011). Characterization of Essential Oil and Effects on Growth of Verbena gratissima Plants Treated with Homeopathic Phosphorus. Natural Product Communications, 6, 1-6.

Tim, J., Claudia, S., Meinhard, S., Peter, H., \& Stephan, B. (2010). Effects of Homeopathic Arsenicum Album, Nosode, and Gibberellic Acid Preparations on the Growth Rate of Arsenic-Impaired Duckweed (Lemna gibba L.). The Scientific World Journal, 10, 2112-2129. https://doi.org/10.1100/tsw.2010.202

Verdi, R., Harthmann, O. E. L., Debarba, R. J., Giesel, A., \& Parizotto, C. (2016). Desempenho de Ocimum basilicum L. sob Efeitos de Preparados Homeopáticos. Cadernos de Agroecologia, 11(2), 10-15.

\section{Copyrights}

Copyright for this article is retained by the author(s), with first publication rights granted to the journal.

This is an open-access article distributed under the terms and conditions of the Creative Commons Attribution license (http://creativecommons.org/licenses/by/4.0/). 